\title{
The House Sparrow is Homeless: A Small Attempt to Conservation
}

\author{
Anandan G*, Kumaresan M, Thomas A, Benickson C, Devi RC, Geethu M, Augustine J, Kavipriya J, Mithun Raj M and Shiva R
}

Thanthai Rover Institute of Agriculture and Rural Development, Perambalur, Tamilnadu, India

${ }^{*}$ Corresponding author: Anandan G, Assistant Professor (Forestry), Thanthai Rover Institute of Agriculture and Rural Development, Perambalur, Tamilnadu, India, Tel: 91-9597149700; E-mail: anandangrowmore@gmail.com

Rec date: Mar 6, 2014 Acc date: Mar 24, 2014 Pub date: Mar 30, 2014

Copyright: @ 2014 Anandan G, et al. This is an open-access article distributed under the terms of the Creative Commons Attribution License, which permits unrestricted use, distribution, and reproduction in any medium, provided the original author and source are credited.

\begin{abstract}
House sparrow is one of the endangering species of recent times. It has various roles to play in the urban environment and also helps to keep the ecological balance. The reasons for its declining are many such as lack of nesting places, lack of food and unwillingness of common man to coexist with it etc. On the whole it is an alarm bell to all to take necessary steps to conserve the small bird. In our college we have taken an initiative step by setting Nest pot in various locations where sparrows noticed and places where chance nesting is positive. We have installed more than 100 nest pot in and around found campuses of the Rover Education Institutions. And we have spread some grains purchased from the markets as a source of food for the sparrows. Our Agricultural department also requested to use organic pesticide rather than broad spectrum insecticides. We see movement of House sparrow here and there near the nest pots.
\end{abstract}

Keywords: House Sparrow; Passer domesticus; Endangered species; Sparrow conservation; Nest pots

\section{Introduction}

It would be a month before when I heard the chirping sound of a sparrow just outside the window. Sparrow is most lovable, small and harmless social bird (Figure 1). Sparrows can be seen anywhere in our surroundings if you are not living in most civilized concrete jungle. You were able to see a sparrow around you whenever you want, some years ago. But today you have to search for a sparrow if you want to show your offspring who always look at the fool's box, the TV. If you are running in 30 's it is sure that you have grown by observing this small and beautiful bird. The shocking and the inconvenienced truth is that the population of sparrow is declining at fastest pace.

\begin{tabular}{|l|l|} 
The house Sparrow's scientific name is & $\begin{array}{l}\text { The scientic classification is as } \\
\text { follows: } \\
\text { Phylum: Chordata } \\
\text { Sub-phylum: Vertebrata } \\
\text { Class: Aves } \\
\text { Order: Passeriformes } \\
\text { Genus: Passer } \\
\text { Species: domesticus } \\
\text { Commonname: House Sparrow }\end{array}$ \\
Figure 1: Taxonomy and scientific classification
\end{tabular}

\section{Description}

Generally, sparrows are small, plump, brown-grey birds with short tails and stubby, powerful beaks. The differences between sparrow species can be subtle. House Sparrow is a small song bird, males and females can be differentiated distinctly; the male have black throat white cheeks and black Bib while the female have brown colour with eye stripe. The average size is $14-16 \mathrm{cms}$ and weight is nearly $26-32$ grams. It is a small bird and beak is thick, legs are short with pale pink in color [1].

One peculiar behavior of House Sparrow is dust bathing. The sparrows will first scratch a hole in the ground with their feet, then lie in it and fling dirt or sand over their bodies with flicks of their wings. They will also bathe in water, or in dry or melting snow. Water bathing is similar to dust bathing, with the sparrow standing in shallow water and flicking water over its back with its wings, also ducking its head under the water [2].

\section{Habitat and food habit}

House Sparrows like areas that have been modified by humans, including farms, residential and urban areas. They are attracted to buildings for roosting and shelter. They used to build their nest in thatch roofs, sun shades, any nook or cranny, lofts, kitchens, exhaust holes, hanging baskets, unused poles with end caps, garden trees, shrubs etc. [3].

Sparrow's main diet consists of grain seeds, especially grains from waste and animal feed stock. Alternative to seed diet is very wide varies from arthropods such as small insects, larva of mosquitoes, butterflies, and garbage chuck by human. At the time of spring they prefer to feed on flowers with yellow colour, fruits etc. [4].

\section{Importance of house sparrow}

Every organism in this planet has its own role to play and participate. As a sixth sensed, civilized animals we never thought of others co exiting members of the family. Simply concentration on one species' improvements and facilitation more luxury which are all paving path to no way back town. Here look at the importance of most affected common species of the ecosystem $[5,6]$.

Maintaining the ecological balance: Sparrow is a very important member of various urban and natural food chains and food webs. It 
feeds on grains like rice, wheat, cumbu etc. and also on larva of mosquitoes, dragon fly etc. There are numerous examples are there to highlight. In 1850, to control the green inch worms which destroyed thousands of trees in the New York City Park, house sparrow was introduced to Brookly Institute, United State. The problem was under control and now it is a common bird of US. The chick stage is insect eating phase for sparrows' feeds on small insect of garden. It has proven well suited for studies if general biology such as evolutionary mechanism, temperature metabolism and pest control.

It also feeds on larva of mosquitoes which breeds in the water stagnated in the in accessible area of house. The sparrows go in search of larva and feeds on them. This mechanism is a natural pest control process in which human being also favored without any expenses [6].

Brings prosperity: Sparrows bring prosperity for us, We like to watch this small and lovable bird. Our children always want to observe this bird and always sing songs related to this bird to entertain themselves.

Plant pollination: Pollination is the process of pollen transfer to the female flower as a part of sexual reproduction. Sparrow visit many flowers in a day food. At the time of visit they carry pollen and dropped in the female flower that leads to fertilization of the flower. In such a sparrow is very important for pollination.

\section{Reasons for population decline}

House Sparrow is listed in Red Data Book of International Union for Conservation of Nature (IUCN) which is an alarm bell to us. Reasons for sparrow number decline are numerous ranges from mythology to mentality of a common man. List of factors are listed below:

Loss of habitat: This is the primary factor that vanished sparrows from the streets and houses. Evaluation of architecture eroded thatched roof and tiles house from the society also. Due to modern technology old spacious buildings have been changed to the shapes where sparrows do not find their habitat. It is the most important reason of decline of population $[7,8]$.

Lack of food: Sparrow flocks fly around 1.5 to 2 miles in searching of food such as grains, insects etc. In the modern life style people tend to buy things in pocket which are pre cleaned or dried. Chance of cleaning and drying the grains in front of the house, balconies, and top floors is very less now a days [8]. This has led to scarcity of food for these tiny scavenging social birds. Many of the local road side corner shops has been closed due to florishment of modern departmental store in which we get everything in pockets packed somewhere kilometers away and also provide little chance to find spill over grains on the roads. On the other hand, in the modern agriculture, insects are the second most feed for the young chicks. Usage of broad spectrum insecticides has let the availability of insect feed to very minimum. It also affects accessibility of poison less fruits. Recent survey reveals that sparrows are spotted near organic fields and perching on the ground for food.

Modern lifestyle: Changing lifestyles have robbed sparrows of their nesting grounds. The fast paced lifestyles of urban and semi-urban areas have also reflected in people's attitude towards birds and biodiversity. Previously, people used to share a symbiotic relationship with animals and birds and also accepted co-existence. They would not mind sparrows build nests in their houses and places where access is limited to a common man. In the modern era, especially the luxurious life style people want birds to be inside the cages not out of their control or free living birds. The new buildings and landscaped gardens which are being constructed are not at all sparrow friendly. The modern glass-clad match box shape buildings do not have cavities which are important for sparrows to make nests [9]. Building of nest in the windows, sunshades, AC ducts thought to an ugly in appearance to the million dollar buildings. According to one study, use of unleaded petrol may also have a critical impact on the sparrow decline. At the time of combustion of unleaded petrol produces methyl nitrate which is highly toxic to the small insects which forms major part of sparrow $\operatorname{diet}[10,11]$.

Loss of tree canopy: In the industrialized era of development we construct bazaars, mega buildings and even city government tent to extend the width of the road sides for which the urban trees are cut down without understanding ecological importance of the trees or simply ignoring the reality fact.

Cell phone towers: Environmental experts say that sparrow is not able to withstand the microwave impact from cell phone towers. Due to that the immune system and reproductive abilities are being badly affected, which has resulted in a situation where the erstwhile ubiquitous sparrow is now rarely seen in urban areas. But it a recent research by Encyclopedia of environmental health argues that there is no strong evidence on negative relationship between vanishing sparrows and electromagnetic waves from cell phone tower. It is believed that the magnetic waves are affecting the eggs of the sparrows but not scientifically proven as the cell phone tower waves are nonionizing waves which has not deal with cell, DNA etc. [12].

\section{Sparrow Conservation}

It is the time to take fruitful efforts to conserve the tiny social, human associated bird.

It is our responsibility to save this small, lovable, beautiful and harmless bird for environment and for ourselves. It required part of your heart and little effort that may create great impacts in the life system of house sparrows [13-15].

\section{Some important tips to save sparrows}

Spill over the rejected grains from your household rather than dump them in the dust bins. This activity will provide a little chance to food availability for the little companion (Figure 2).

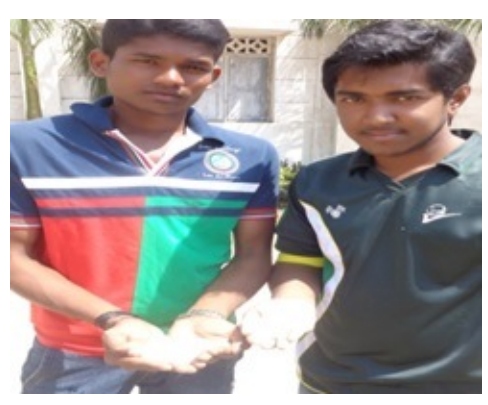

Figure 2: Project students with grains on hand 
Install small sparrow boxes in and around the window, stair cases, and balconies wherever chance of sparrow visit is possible (Figures 3 and 4). The box should be of any kind. That should not get wet when rain, should have one hole access, not reachable by monkey and long durable too. See model picture of the sparrow box. Or simply hang a pot with lid on top and access point in the side (Figure 5).

Place a small cup or bowl of water just near bird nesting area to have water bath or to drink. At the summer time arrives this may help the birds to avoid dehydration and get ride thirsty.

Wisely use of insecticides and pesticides. In the agricultural field the insecticide application must be minimized. If required instead of inorganic poison, harmful insecticide, application of poison less ecofriendly organic insecticides such as Panchakavya, Dasa kaviya should be recommended. Over use of these substances are harmful in many ways.

Use high quality of fuel in your vehicle is also a critical point to save the sparrow.

Last but not least, wherever you see sparrow nest, inside your home or around your premises, please don't disturb for simple reasons. Try to help them to get some food nearby by throwing grains.

\section{World Sparrow Day-20th of March}

World Sparrow Day is celebrated on March 20 worldwide. The theme for celebrating World Sparrow Day is not only to commemorate the event for a day, but also to use it as a platform to highlight the need to conserve sparrows as well as urban biodiversity. The event targets to bring together like minded individuals, national and international level groups. The aim is also to attract the attention of government agencies and the scientific community to take notice of the need for the conservation of the common bird species and urban biodiversity. For instance, in the October, 2012, Delhi Government has announced House Sparrow as State Bird. It is one of the mile stone in the conservation of the bird and also to emphasis on magnitude of action required to conserve the smaller bird. You can also get involved yourself by just visiting a website: http://www.citizensparrow.in/. In which you can contribute by entering your data of recent house sparrow sitting. Meanwhile you can also get field level information on house sparrow status in the same web page as it is funded by Bombay Natural History Society (BNHS) and Ministry of Environment and Forest, etc.

\section{What we Do?}

We are the staff and students of Thanthai Roever Institute of Agriculture and Rural Development, Affiliated to Tamil Nadu Agricultural University, Perambalur District, and Tamilnadu State, India. Roever Group of Institution is providing various degrees and diploma programmes in Engineering, Agriculture, Nursing and we are also running primary, secondary and higher secondary schools. These institutions are located in four major location of Perambalur district. As a part of Roever Institutions, our college is offering diploma and degree in Agriculture and Horticulture sciences. Our college is located on the national high way of Trichy to Chennai with an area of more than 50 acres.

Our final year students, as a part of academic curricular, in the department of Forestry, are undergoing a project work on' Plant Diversity Index study and it importance in four campuses of Roever Institutions. One part of the project is 'Conservation of House
Sparrow and facilitating their survival in and around the Roever Institutions'. In that we have installed more than 100 sparrow pots in the four campuses where occurrence sparrow sights is often. We have installed these sparrow pots in various locations such as under the tree cover, windows with holes, AC ducts, two wheeler stands, bathroom corners, verandas, room that are not frequently used but access to sparrows etc. Apart from that we have collected grains from the local shops and broad casted in and around all campuses to facilitate food availability to the sparrows. We are also requested the entire department in the Agricultural college not to use inorganic pesticides to conserve the young larva as source of feed to young chicks.

In some of the installation we have notices sparrow visits with pair, nesting activities. Apart from that we have noticed frequent visit by Common Mynas and Browny Mynas etc. it is our duty to convey the message of responsibility along with the professional knowledge. Now students are taking individual interest to install more sparrow pots and also take special care to safe guard the sparrow.

\section{Samples of our team efforts towards conservation of house sparrow:}



Figure 3: One of our project student tying a nest pot in the window of our office

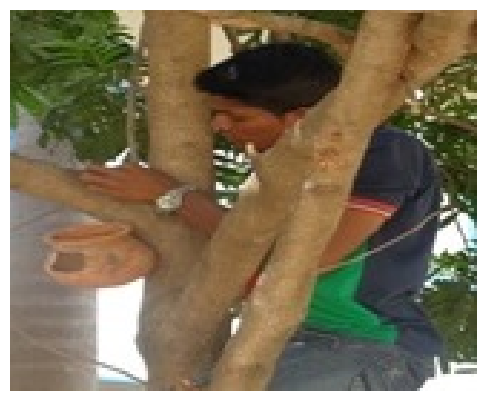

Figure 4: Our team student is tying a nest pot under a tree crown 
Citation: Anandan G, Kumaresan M, Thomas A, Benickson C, Devi RC, et al. (2014) The House Sparrow is Homeless: A Small Attempt to

Page 4 of 4

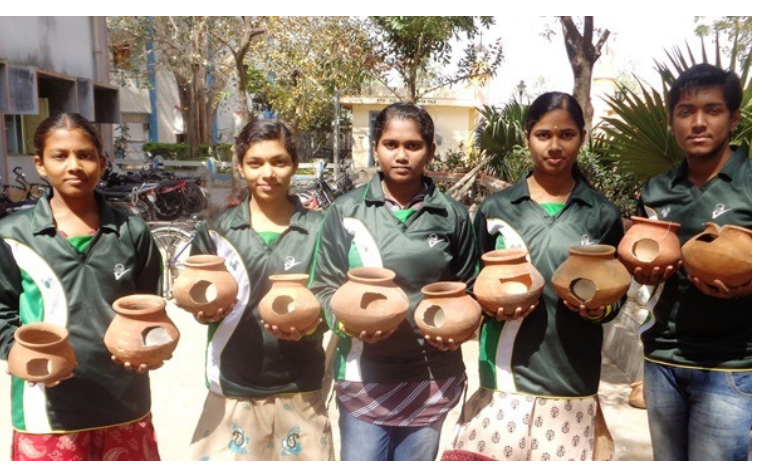

Figure 5: Our team with nest pots

Let put hands and heart together to conserve little homeless House Sparrow

\section{References}

1. Ali S, Ripley SD (1987) Handbook of the birds of India and Pakistan. 2nd Edn, Oxford University Press, New Delhi, India.

2. Balakrishnan P (2005) A survey report on the House Sparrow Passer domesticus in south India. Malabar Trogon 3: 4-6.

3. Balakrishnan P, Jijeesh N, Kurikkal MS, Maya T, Lijitha MP (2011) Distribution, abundance and nest site characteristics of the House Sparrow Passer domesticus in Manjeri Municipality, Kerala. Technical
Report submitted to Wildlife Research and Conservation Trust. NSS College, Manjeri, India.

4. Chapman FM (1896) Hand book of Birds of Eastern North America. D.Appleton and Company, Newyork, USA.

5. Dandapat A, Banerjee D, Chakraborty D (2010) The case of the Disappearing House Sparrow (Passer domesticus indicus). Vet World 3: 97-100.

6. Rajashekar S, Venkatesha MG (2008) Occurrence of house sparrow, Passer domesticus indicus in and around Bangalore. Curr Sci 94: 446-449.

7. Ghosh S, Kim KH, Bhattacharya R (2010) A survey on house sparrow population decline at Bandel, West Bengal, India. J Korean Earth Sci Soc 31: $448-453$.

8. Joshi DK (2009) House Sparrow (Passer Domesticus): The Endangered Bird. Orissa, Review: 53-55.

9. Balaji S (2014) Artificial nest box for house sparrow: An apt method to save the dwindling species in an urban environment. International Journal of Biodiversity and Conservation 6: 194-199.

10. Daniels RJR (2008) Can we save the sparrow. Current Science, 95: 1527-1528.

11. Vijayan VS (2003) Where have all the sparrows gone? Down to Earth, New Delhi, India.

12. The Hindu (2013) Cell phone radiation may be harmful, but not lethal. Chennai, India.

13. "Passer domesticus", Animal Diversity.

14. The Hindu (2012) Campaign to save the House Sparrow. Dehradun, India.

15. The Hindu (2012) Spare a thought for the sparrow. 